\title{
ANALYSIS OF SUPERIOR CROPS LOCATION IN EAST JAVA, INDONESIA
}

\author{
Hanifatus Sahro ${ }^{1,2 *}$, Shwu-En Chen ${ }^{2}$, Sujarwo $^{1}$ \\ ${ }^{1}$ Faculty of Agriculture, Brawijaya University, Indonesia. \\ ${ }^{2}$ Program in Agribusiness Management, National Pingtung University of Science and Technology, Taiwan \\ *corresponding author: hanifatuszahro.12@gmail.com
}

\begin{abstract}
Regional development is an important aspect in improving the regional economy, and its relationship with the national economy. East Java Province is one of the regions with the most potential agricultural sector and is the highest national granary area in Indonesia. Maximizing the potential of the resources owned by East Java will accelerate the development process and increase the regional and national economy. For the economic growth, this study aims to examine the crops performance to estimate the pattern of regional economic growth in East Java. The time series data of East Java Central Bureau of Statistics from 2008 to 2017 are adopted. The location quotient analysis and shift-share analysis with three indicators, namely regional economic growth, proportional shift growth, and differential shift, are used. The results showed that crops such as corn, green beans, peanuts, soybeans, rice, sweet potatoes, and cassava in 29 districts and 9 cities of East Java have crucial performance and economic growth patterns. As the results, to consider and identify priority policy plans to accelerate regional economic development and growth are suggested.
\end{abstract}

Keywords: Crops, Economic Growth, Regional Development, Shift-Share

http://dx.doi.org/10.21776/ub.agrise.2021.021.1.7

Received 22 July 2020

Accepted 28 January 2021

Available online 31 January 2021

\section{INTRODUCTION}

Law of Republic Indonesia No. 23 of 2014, it was stated that local governments have the authority and obligation to regulate and manage their own government affairs and the interests of local communities. The implementation of regional autonomy is a form of government support to local governments in managing and developing their regions in accordance with the conditions and potential of each region. The success of the development of an area is directly affected by the participation of the regional government because the government as a policy holder has full rights and authority in regulating and delivering policies to the community. Regional development can encourage increased equity, stability, growth, and community welfare as the main actors of development (Wulandari, 2010).

Regional development that can be pursued by the government can be through potential sectors, one of which is the agricultural sector in East Java. East Java is the second largest contributor to the Indonesian economy with a growth rate similar to the national level (World Bank, 2011), has the largest number of agricultural households 7,212.12 households (Inter-Census Agriculture Survey, 2018), and also one of the main granaries with large amounts of land used for crops, especially rice (Ministry of Agriculture, 2018). Crops are the biggest contributor to East Java's GRDP compared to other sub-sectors which tend to increase every year. In 2013 to 2016 the contribution has always been increasing, but in 2017 it decreased from 4.39 to 3.90 , but this contribution remains the biggest contribution among other agricultural sub-sectors (BPS East Java, 2017). High contribution of food crops has become an opportunity for East Java Province to continue to develop the sub sector.

To continue improve the prosperity and regional economy of East java, local governments need to improve competitiveness through the concept of development that relies on local characteristics and potentials in the form of the agricultural sector as the focus of development. Therefore, this study aims to examine the crops performance to estimate the pattern of regional economic growth in East Java so it can be used as a reference for local governments to develop regional economic improvement strategies.

Isserman (1977), explained that in planning to estimate regional economic impacts can be done with a location-quotient approach. This LQ analysis is used to determine the pre-eminent subsector or 
economic basis of a regional economy. The technique is frequently used with economic data where it is a short-cut technique to determine where industries are concentrated and which economic sectors produce for the export market. LQ analysis can be used to determine superior commodities based on basic economic theory, especially from the aspect of supply (production or population).

To identify developing sectors or commodities and to show the reasons for growth, a shift-share analysis was carried out (Kerna \& Harris, 2009), which was the analysis first developed by Dunn (1960). According to Fernandez, Lopez, and Perez (2007). An important component of this statistical technique is the calculation of geographical changes in economic trends (Fernandez, Lopez, and Perez, 2007). In addition, shift-share also using for export analysis such as to identify the export opportunities of Malaysia's palm oil (Asfaranjan and Moayyed, 2012), to identify the potential country for rubber export from Malaysia (Rahman, et.al, 2014), and to examine the export performance of china electronics (Wilson, et.al, 2005). Another studies was conducted by Shi and Yang (2008) using the shift-share to tourism industry, and also the spatial shift share to identify the electricity consumption changes across italian regions (Grossi and Mussini, 2018).

In this research using the LQ to identify the basic and non-basic crops, as well as using shift-share for regional economic analysis, concurred by Reynolds (1980) use the shift share for analyzing the growth of sectoral and regional productivity in contemporary Mexico, and also by Hassan, et.al (2011) to examine the new development ECER in Malaysia from the perspective of regional. Other than that, Fothergill and Gudgin (1979) proved that the shift-share technique is an appropreate tool to analyze regional growth in the United Kingdom. This is also concurred by Tervo and Okko (1983), who opined that shift share analysis can be used for analyzing regional growth. In addition, Khusaini (2015) probing into the spatial competitiveness of economic sectors in Banyuwangi by applying a shift share model.

\section{RESEARCH METHODS}

The study was purposively conducted, namely in the East Java Province of Indonesia, with the consideration that the East Java Province was designated as a national food barn, and the agricultural sector in East Java Province was one of the largest foreign exchange contributors to the Indonesian State. The study was conducted using secondary data obtained from several sources, namely from the East Java Agriculture Service, East Java Central Statistics Agency (BPS), and the Indonesian Central Bureau of Statistics (BPS). The data used are production time series data of seven crops at 38 regions (29 districts and 9 cities) in East Java Province during 2008-2017. The seven crops, including corn, green beans, peanuts, soy, rice, sweet potato, and cassava, are the major crops in East Java Province

\section{Data Analysis}

\section{Location Quetient (LQ) Analysis}

LQ analysis used to determine the superior sub sector of the regional economy. In this study uses the Production Location Quotient (PLQ) to identify superior crops in each region of East Java Province by the formula (Isserman, 1977):

$$
P L Q_{i}=\frac{E_{i j}}{E_{j}} / \frac{E_{i n}}{E_{n}}
$$

Where:

$E_{i j}=$ the production of crop $i$ in region $j$

$E_{j}=$ total crops production in region $j$

$E_{i n}=$ the production of crop $i$ in East Java Province

$E_{n}=$ total crops production in East Java Province

The LQ criteria are:

- LQ> 1 means that the crop has a comparative advantage, become superior or become a source of growth in the region. Superior commodities can not only meet the needs in the area concerned but can also be exported outside the region.

- $\mathrm{LQ}=1$ means that the crop in question is classified as non-superior, because it does not have a comparative advantage. the commodity is only able to meet its own regional needs and is unable to be exported.

- $\quad$ Q $<1$ means that the crop is non-superior commodity. The commodity in the area requires import from the outside because it cannot meet the needs of the region it self.

\section{Shift Share Analysis}

To examine the crops performance in relation to regional economic performance in East Java using shift-share analysis. This analysis can be used to explain economic change as a combination of three influential factors, namely:

- Regional economic growth

- Proportional shift

- Differential shift

The shift-share analysis method chosen in this study is due to its clarity and simplicity, so this method is suitable for use in regional economic growth analysis (Goschin, 2014). The following formula is used:

$$
\begin{aligned}
& D_{i j}=N_{i j}+M_{i j}+C_{i j} \\
& D_{i j}=Y_{i j}^{*}-Y_{i j} \\
& N_{i j}=Y_{i j} r_{n} \\
& M_{i j}=Y_{i j}\left(r_{i n}-r_{n}\right)
\end{aligned}
$$




$$
C_{i j}=Y_{i j}\left(r_{i j}-r_{i n}\right)
$$

Where:

$D_{i j}=$ Production changes of crop $i$ of district $j$ from the aerly year to the final year

$N_{i j}=$ Regional economic growth of crop $i$ of district $j$

$M_{i j}=$ Proportional shift of crop $i$ of district $j$

$C_{i j}=$ Differential shift of crop $i$ of district $j$

$Y^{*}{ }_{i j}=$ Production of crop $i$ of district $j$ in the final year

$Y_{i j}=$ Production of crop $i$ of district $j$ in the early year

$r_{n}=$ Agregate production growth rate of East Java Province

$r_{i n}=$ Production growth rate of crop $i$ of East Java Province

$r_{i j}=$ Production growth rate of crop $i$ of district $j$

Base on the Shift-Share Analysis, the criteria are (Hardiani and Lubis, 2017):

- If $M_{i j}>0$, the production of crop i of district j grows competitively because East Java provincial level grows faster. Conversely, if $M_{i j}<0$, the production of crop i of district $\mathrm{j}$ declines because East Java provincial level grows slowly.

- If $C_{i j}>0$, the production of crop $\mathrm{i}$ of district $\mathrm{j}$ grows faster than the provincial level. Conversely, $C_{i j}<0$ means the production growth of crop $i$ of district $j$ is relatively slower than the crop i production growth in East Java Province.

\section{RESULTS AND DISCUSSION}

\section{Superior Crops Production in East java}

The concept of regional competitiveness (Khusaini, 2015) can be referred to as the ability of a region to produce goods and services that are in accordance with the needs of the international market, as well as being able to provide and maintain high and sustainable incomes. Widyantoro (2005) states that a commodity in the regional or local become superior if the commodity is not only sold in the local market, but also sold outside the region, thus showing that the commodity has a strong competitiveness in the regional market and outside the region. Locationquotient analysis in this study is adopted to determine if the crops are superior or non-superior at region of East Java Province. Based on the analysis, the LQ values of seven crops, corn, green beams, peanuts, soybeans, rice, sweet potato, and cassava, at 38 regions in East Java Province are shown in Table 1.
The crops with LQ values greater than one are the superior commodities at the region. In Pacitan district, peanut, soy, and cassava are the superior commodities because in the LQ analysis these commodities have a value more than one. Whereas in Ponorogo, the superior commodities are soy and cassava. Likewise with other regions in accordance with the result shown in Table 1. The results shows that the different regions have different superior commodities.

Table 1. The Result of Location Quotient of Crops Production in East Java Province

\begin{tabular}{|c|c|c|c|c|c|c|c|}
\hline \multirow[b]{2}{*}{ District } & \multicolumn{7}{|c|}{ Commodities } \\
\hline & Corn & $\begin{array}{l}\text { Green } \\
\text { Beans }\end{array}$ & Peanuts & Soy & Rice & $\begin{array}{l}\text { Sweet } \\
\text { Potato }\end{array}$ & Cassava \\
\hline Pacitan & 0.69 & 0.03 & 1.54 & 2.84 & 0.49 & 0.20 & 4.22 \\
\hline Ponorogo & 0.63 & 0.35 & 0.27 & 3.11 & 0.61 & 0.04 & 3.68 \\
\hline Trenggalek & 0.52 & 0.03 & 0.42 & 3.21 & 0.63 & 0.04 & 3.96 \\
\hline Tulungagung & 1.13 & 0.04 & 0.42 & 1.74 & 0.80 & 0.28 & 1.89 \\
\hline Blitar & 1.49 & 0.12 & 0.99 & 1.57 & 0.79 & 0.30 & 1.16 \\
\hline Kediri & 1.54 & 0.01 & 0.62 & 1.20 & 0.74 & 0.58 & 1.23 \\
\hline Malang & 0.97 & 0.01 & 0.32 & 1.82 & 0.68 & 1.79 & 2.59 \\
\hline Lumajang & 1.02 & 0.03 & 0.82 & 0.90 & 1.11 & 1.49 & 0.56 \\
\hline Jember & 1.05 & 0.04 & 0.32 & 1.06 & 1.20 & 0.64 & 0.29 \\
\hline Banyuwangi & 0.62 & 1.03 & 0.18 & 2.94 & 1.34 & 0.94 & 0.33 \\
\hline Bondowoso & 0.97 & 0.04 & 0.07 & 1.03 & 1.01 & 0.27 & 1.37 \\
\hline Situbondo & 1.82 & 0.13 & 0.13 & 0.11 & 0.92 & 0.03 & 0.07 \\
\hline Probolinggo & 1.53 & 0.20 & 0.45 & 0.95 & 0.77 & 0.08 & 1.13 \\
\hline Pasuruan & 0.79 & 0.48 & 0.77 & 1.45 & 1.16 & 0.33 & 0.91 \\
\hline Sidoarjo & 0.01 & 2.32 & - & 0.43 & 1.78 & 0.01 & - \\
\hline Mojokerto & 1.00 & 1.20 & 0.48 & 1.15 & 0.98 & 8.58 & 0.35 \\
\hline Jombang & 1.20 & 0.07 & 0.18 & 0.84 & 1.14 & 0.18 & 0.31 \\
\hline Nganjuk & 0.96 & 0.33 & 0.26 & 2.11 & 1.04 & 0.45 & 1.08 \\
\hline Madiun & 0.25 & 1.42 & 0.21 & 1.31 & 1.44 & 0.46 & 0.87 \\
\hline Magetan & 0.58 & 0.04 & 2.01 & 1.18 & 1.03 & 6.88 & 1.38 \\
\hline Ngawi & 0.50 & 0.08 & 1.04 & 1.88 & 1.21 & 2.14 & 1.04 \\
\hline Bojonegoro & 0.67 & 1.78 & 0.33 & 1.55 & 1.31 & 0.31 & 0.51 \\
\hline Tuban & 1.53 & 1.46 & 4.06 & 0.67 & 0.79 & 0.60 & 0.81 \\
\hline Lamongan & 0.95 & 1.94 & 0.77 & 1.30 & 1.24 & 0.15 & 0.30 \\
\hline Gresik & 0.87 & 1.22 & 0.69 & 0.38 & 1.30 & 0.60 & 0.26 \\
\hline Bangkalan & 0.99 & 1.82 & 7.02 & 1.33 & 0.93 & 2.62 & 0.91 \\
\hline Sampang & 0.78 & 5.19 & 4.66 & 4.79 & 0.73 & 2.08 & 1.99 \\
\hline Pamekasan & 1.46 & 0.81 & 0.81 & 0.93 & 0.89 & 0.32 & 0.74 \\
\hline Sumenep & 1.94 & 5.21 & 0.90 & 1.41 & 0.49 & 0.17 & 1.41 \\
\hline Kediri City & 1.17 & 0.01 & 0.19 & 0.25 & 1.17 & 0.17 & 0.27 \\
\hline Blitar City & 1.67 & - & 0.53 & - & 1.01 & 0.02 & - \\
\hline Malang City & 0.22 & - & 0.23 & 0.90 & 1.42 & 0.25 & 1.11 \\
\hline $\begin{array}{l}\text { Probolinggo } \\
\text { City }\end{array}$ & 2.53 & 0.01 & 0.05 & - & 0.60 & - & - \\
\hline
\end{tabular}




\begin{tabular}{|c|c|c|c|c|c|c|c|}
\hline $\begin{array}{l}\text { Pasuruan } \\
\text { City }\end{array}$ & - & - & & 0.07 & 1.81 & - & $\begin{array}{l}\text { The second component of shift-share analysis is } \\
\text { proportional shift, which measures the relative }\end{array}$ \\
\hline $\begin{array}{l}\text { Mojokerto } \\
\text { City }\end{array}$ & 0.01 & 1.43 & & 6.23 & 1.63 & - & $\begin{array}{l}\text { changes in the economic growth or decline of each } \\
\text { region compared to the economy of East Java }\end{array}$ \\
\hline Madiun City & - & 0.63 & 0.01 & 0.50 & 1.80 & - & Province. This measurement shows whether the \\
\hline $\begin{array}{l}\text { Surabaya } \\
\text { City }\end{array}$ & 0.13 & 0.23 & 0.03 & 0.21 & 1.69 & 0.11 & $\begin{array}{l}\text { economy in the region is concentrated in a sector that } \\
0.29 \text { is growing faster than the economy of East Java }\end{array}$ \\
\hline Batu City & 0.68 & - & 0.66 & 0.47 & 0.87 & 15.73 & 1.14Province. \\
\hline
\end{tabular}

Source: This Study (2019)

\section{Crop Growth Pattern and Growth Components in East Java}

The results of the shift-share analysis in Table 2 show that the crops in each region in East Java has a different performance and different pattern. The growth patterns of crops in the southern sub-regional namely Pacitan, Ponorogo, Trenggalek, Tulungagung, Blitar, Blitar City, Kediri, Kediri City, Malang and Malang City show that commodities that have increased production growth rates during the period 2008 to 2017 are cassava, corn and rice, so it can be stated that the three commodities can be developed to improve the economy of the southern sub-regional. Cassava in general can adapt widely from the lowlands to the highlands, on fertile and marginal lands, so that these plants can grow in almost all regions of Indonesia (Saleh, et al., 2016). While commodities which tend to have low production growth in the southern sub-regional is soybean.

Growth pattern in the far-southeast subregional consisting of Lumajang, Jember, Banyuwangi, Bondowoso, Situbondo, Probolinggo, and Probolinggo City, commodities with a production growth rate that tends to increase from 2008 to 2017 are rice and corn. It can be concluded that in the farsoutheast sub-regional is a production centers of rice and corn, and both of these commodities that can be developed to improve the regional economy.

Similar to the far-southeast sub-regional, in Surabaya sub-regional (Pasuruan, Pasuruan City, Surabaya, Sidoarjo, Mojokerto, Mojokerto City, Lamongan and Gresik) and Northwest sub-regional (Jombang, Nganjuk, Madiun, Madiun City, Magetan, Ngawi, Tuban, and Bojonegoro) commodities that have increased production growth are rice and corn commodities. The high production of corn and rice in some of these areas is related to the UPSUS (Special Efforts) program to increase rice, corn and soybean production organized by the government in order to achieve food self-sufficiency. The sub-regional madura consists of corn, cassava and peanuts with an increased production growth rate.

The first component in the shift-share analysis is regional economic growth. The highest value in the regional economic growth it's mean the commodity growing faster than other crops, while the least significant commodities it's mean this commodity has the lowest growth rate among other crops
Table 2.The Change of Crop Production in East Java

\begin{tabular}{|c|c|c|c|c|c|c|c|}
\hline \multirow[b]{2}{*}{ District } & \multicolumn{7}{|c|}{ Commodities } \\
\hline & Corn & $\begin{array}{l}\text { Green } \\
\text { Beans }\end{array}$ & Peanuts & Soy & Rice & $\begin{array}{l}\text { Sweet } \\
\text { Potato }\end{array}$ & Cassava \\
\hline Pacitan & $-3,247$ & -15 & -482 & -311 & 5,261 & -121 & 34,526 \\
\hline Ponorogo & 7,024 & -107 & 18 & $-65,974$ & 4,161 & -5 & 11,028 \\
\hline Trenggalek & 2,079 & 19 & -398 & $-34,659$ & 4,933 & -16 & $-2,045$ \\
\hline Tulungagung & 16,664 & -9 & -575 & $-19,863$ & 5,692 & -240 & -241 \\
\hline Blitar & 7,169 & -50 & -620 & $-8,959$ & 8,635 & 368 & 5,262 \\
\hline Kediri & 8,678 & -13 & -183 & $-19,575$ & $-4,011$ & 680 & 4,670 \\
\hline Malang & $-2,067$ & -18 & -86 & $-53,076$ & 2,061 & 1,655 & $-6,053$ \\
\hline Lumajang & 2,085 & -16 & -557 & $-7,988$ & 8,346 & 1,005 & $-3,073$ \\
\hline Jember & 24,867 & -34 & -668 & $-6,721$ & 15,709 & 213 & $-3,436$ \\
\hline Banyuwangi & 6,823 & $-1,088$ & 203 & $-2,673$ & 14,618 & 31 & $-2,127$ \\
\hline Bondowoso & $-2,402$ & -13 & -70 & $-11,945$ & 14,630 & -26 & 2,069 \\
\hline Situbondo & 1,078 & -41 & -55 & -524 & 12,596 & -6 & 285 \\
\hline Probolinggo & 1,194 & -47 & -285 & $-10,554$ & 979 & -126 & $-13,692$ \\
\hline Pasuruan & 16,959 & -367 & $-1,491$ & $-9,918$ & 26,677 & 243 & $-7,101$ \\
\hline Sidoarjo & 138 & -140 & -4 & -367 & 3,173 & -31 & -16 \\
\hline Mojokerto & 5,891 & -298 & -218 & $-6,209$ & 5,651 & 4,775 & 40 \\
\hline Jombang & 8,261 & -24 & -158 & $-1,473$ & 4,414 & 68 & -99 \\
\hline Nganjuk & 6,092 & -104 & -145 & $-12,753$ & 9,386 & 290 & -924 \\
\hline Madiun & 1,596 & -449 & -11 & $-5,807$ & 15,370 & 1,122 & $-1,989$ \\
\hline Magetan & 1,876 & -7 & -871 & $-9,011$ & 13,470 & 2,344 & 2,980 \\
\hline Ngawi & 13,405 & -50 & $-1,824$ & $-16,497$ & 18,573 & 465 & -903 \\
\hline Bojonegoro & $-1,069$ & -698 & 638 & $-9,089$ & 17,633 & 292 & 4,724 \\
\hline Tuban & 14,568 & $-1,208$ & $-4,504$ & $-11,139$ & 14,772 & -15 & $-4,722$ \\
\hline Lamongan & 11,479 & -787 & 343 & $-2,579$ & 14,026 & 73 & 989 \\
\hline Gresik & 4,485 & -169 & -334 & $-1,389$ & 15,976 & 327 & $-1,219$ \\
\hline Bangkalan & -746 & -347 & $-4,673$ & $-4,993$ & 12,198 & 192 & $-3,443$ \\
\hline Sampang & $-8,607$ & $-1,635$ & $-1,019$ & $-15,017$ & 9,801 & -299 & $-15,328$ \\
\hline Pamekasan & $-1,376$ & -63 & -23 & $-4,262$ & 2,816 & -82 & -938 \\
\hline Sumenep & $-1,399$ & $-1,142$ & 8 & $-8,883$ & 9,478 & -49 & $-16,328$ \\
\hline $\begin{array}{l}\text { City of } \\
\text { Kediri }\end{array}$ & 359 & 0 & -9 & -59 & -109 & -6 & -45 \\
\hline City of Blitar & 167 & 0 & -10 & 0 & -461 & -3 & 0 \\
\hline $\begin{array}{l}\text { City of } \\
\text { Malang }\end{array}$ & -112 & 0 & -8 & -303 & 411 & -16 & 49 \\
\hline $\begin{array}{l}\text { City of } \\
\text { Probolinggo }\end{array}$ & 611 & -1 & -6 & 0 & 539 & 0 & -4 \\
\hline $\begin{array}{l}\text { City of } \\
\text { Pasuruan }\end{array}$ & -18 & 0 & 0 & -9 & 35 & 0 & 0 \\
\hline
\end{tabular}




\begin{tabular}{|c|c|c|c|c|c|c|}
\hline $\begin{array}{l}\text { City of } \\
\text { Mojokerto }\end{array}$ & -5 & -4 & 0 & -4 & 56 & 0 \\
\hline $\begin{array}{l}\text { City of } \\
\text { Madiun }\end{array}$ & -4 & -2 & -2 & -17 & 10 & 0 \\
\hline $\begin{array}{l}\text { City of } \\
\text { Surabaya }\end{array}$ & 14 & -1 & -4 & -37 & 255 & -19 \\
\hline City of Batu & -178 & 0 & -3 & -65 & -457 & 112 \\
\hline
\end{tabular}

Source: This Study (2019)

The last component is a component of competitive advantage or differential shift. The calculation shows how far the competitiveness of a sector in region is compared to the same sector in East Java Province. For the differential shift some sectors in the region had positive competitive shares, and others had negative shares. Those with positive competitive share components were of two categories: (1) those with growth rates above the national average growth rate; and (2) those sectors with growth rates below the national average. Those sectors that experienced above national average growth rates were favored due to the local comparative advantage. The sectors with negative competitive-components are affected by sub optimal comparative local advantage and their growth rates are generally below the national average (Akpadock, 1996).

Based on the value of differential shift $\left(C_{i j}\right)$ and proportional shift $\left(M_{i j}\right)$, the sectors in the District of East Java Province can be divided into four quadrants (Hardiani \& Lubis, 2017):

Quadrant I ( $M_{i j}$ and $C_{i j}$ are positive): The sector has a fast growth rate and is also able to compete with other sectors of the economy from other regions.

Quadrant II ( $M_{i j}$ is negative, $C_{i j}$ is positive):

This sector group has a strong level of competitiveness but the rate of growth is slow. In general, the sector has the potential to be developed.

Quadrant III ( $M_{i j}$ is positive, $C_{i j}$ is negative):

This sector is categorized as an economic sector that has a fast growth rate, but the sector is not able to compete with the economic sectors of other regions because of its weak competitiveness.

- $\quad$ Quadrant IV ( $C_{i j}$ and $M_{i j}$ are negatives): This sector is categorized as a sector whose growth rate is slow and competitiveness is weak.

An interesting phenomenon that occurs in all regions in East Java based on the results of this shift share analysis is that crops in each region are only divided into 2 groups, namely quadrant II and quadrant IV because the value of the proportional shift of all commodities is negative in all regions.

\section{Research Finding and Policy Implication}

In determining the area of crops production centers in each region in East Java should be directed
${ }_{0}$ to the region that do have the potential for developing these commodities. The existence of the production ${ }_{0}$ center area becomes important as a reference location for the government to make investments and regional

-41 development, and in particular in an effort to achieve efficiency, effectiveness and added value. In addition,

88 the existence of the production center area is expected to also be one of the efforts in optimizing the empowerment of the existing spatial structure and can facilitate the formulation of support for the construction of facilities and infrastructure to support agricultural activities. Based on the results of the Location Quotient and Shift Share analysis, each region can be classified with its superior crops as shown in Table 3. it can be seen that each region in East Java has different potential crops, therefore the government should also set regulations and provide different facilities in each region according to their potential respectively.

From Table 3 we can find, there is some superior commodities that have strong competitiveness, but the growth rate is low. For example in the Pacitan region, the main commodities are peanuts, soy, and cassava. These three commodities have strong competitiveness in Pacitan, but the soybean commodity has a low growth rate so that the development prospects are slower than peanuts and cassava. Likewise with other leading commodities in other regions.

Table 3. Superior Crops in Each Region of East Java

\begin{tabular}{|c|c|c|c|}
\hline Regional & Sub-Regional & List by Crops & $\begin{array}{c}\text { List by } \\
\text { Different } \\
\text { Crop Item }\end{array}$ \\
\hline \multirow[t]{11}{*}{ Southern } & Pacitan & $\begin{array}{l}\text { Peanuts, soy, } \\
\text { and cassava }\end{array}$ & Soy \\
\hline & Ponorogo & $\begin{array}{l}\text { Soy and } \\
\text { cassava }\end{array}$ & - \\
\hline & Trenggalek & $\begin{array}{l}\text { Soy and } \\
\text { cassava }\end{array}$ & - \\
\hline & Tulungagung & $\begin{array}{l}\text { Corn, soy, } \\
\text { and cassava }\end{array}$ & Corn \\
\hline & Blitar & $\begin{array}{l}\text { Corn, soy, } \\
\text { and cassava }\end{array}$ & Corn \\
\hline & Blitar City & Corn, and rice & - \\
\hline & Kediri & $\begin{array}{l}\text { Corn, soy, } \\
\text { and cassava }\end{array}$ & Corn \\
\hline & Kediry City & Corn, and rice & Corn \\
\hline & Malang & $\begin{array}{l}\text { Soy, } \\
\text { potato, and } \\
\text { cassava }\end{array}$ & $\begin{array}{l}\text { Sweet } \\
\text { potato }\end{array}$ \\
\hline & Malang City & $\begin{array}{l}\text { Rice, } \\
\text { cassava }\end{array}$ and & Rice \\
\hline & Batu City & $\begin{array}{l}\text { Sweet potato, } \\
\text { and cassava }\end{array}$ & - \\
\hline \multirow[t]{6}{*}{$\begin{array}{c}\text { Far- } \\
\text { Southeast }\end{array}$} & Lumajang & $\begin{array}{lr}\text { Corn, rice, } \\
\text { and } & \text { sweet } \\
\text { potato } & \end{array}$ & $\begin{array}{l}\text { Sweet } \\
\text { potato }\end{array}$ \\
\hline & Jember & Corn, and soy & Corn \\
\hline & Banyuwangi & $\begin{array}{l}\text { Green bean, } \\
\text { soy, and rice }\end{array}$ & - \\
\hline & Bondowoso & $\begin{array}{l}\text { Soy, rice and } \\
\text { cassava }\end{array}$ & Rice \\
\hline & Situbondo & Corn & - \\
\hline & Probolinggo & Cassava & - \\
\hline
\end{tabular}




\begin{tabular}{|c|c|c|c|}
\hline & $\begin{array}{l}\text { Probolinggo } \\
\text { City }\end{array}$ & Corn & Corn \\
\hline \multirow[t]{8}{*}{ Surabaya } & Pasuruan & Soy, and rice & Rice \\
\hline & Pasuruan City & Rice & - \\
\hline & Surabaya City & Rice & - \\
\hline & Sidoarjo & $\begin{array}{l}\text { Green bean, } \\
\text { and rice }\end{array}$ & - \\
\hline & Mojokerto & $\begin{array}{lr}\begin{array}{l}\text { Corn, } \\
\text { bean, }\end{array} & \text { soen, } \\
\text { and } & \text { sweet } \\
\text { potato } & \end{array}$ & $\begin{array}{l}\text { Corn, and } \\
\text { sweet } \\
\text { potato }\end{array}$ \\
\hline & $\begin{array}{l}\text { Mojokerto } \\
\text { City }\end{array}$ & $\begin{array}{l}\text { Green bean, } \\
\text { soy, and rice }\end{array}$ & - \\
\hline & Lamongan & $\begin{array}{l}\text { Green bean, } \\
\text { soy, and rice }\end{array}$ & - \\
\hline & Gresik & $\begin{array}{l}\text { Green bean, } \\
\text { and rice }\end{array}$ & Rice \\
\hline \multirow[t]{4}{*}{ Northwest } & Jombang & Corn, and rice & Corn \\
\hline & Nganjuk & $\begin{array}{l}\text { Soy, rice, and } \\
\text { cassava }\end{array}$ & - \\
\hline & Madiun & $\begin{array}{l}\text { Green bean, } \\
\text { soy, and rice }\end{array}$ & Rice \\
\hline & Madiun City & Rice & - \\
\hline
\end{tabular}

Table 3. Continue

\begin{tabular}{|c|c|c|c|}
\hline Regional & Sub-Regional & $\begin{array}{l}\text { List by } \\
\text { Crops }\end{array}$ & $\begin{array}{c}\text { List by } \\
\text { Different } \\
\text { Crop Item }\end{array}$ \\
\hline \multirow{7}{*}{ Madura } & Ngawi & $\begin{array}{l}\text { Peanut, soy, } \\
\text { rice, sweet } \\
\begin{array}{l}\text { potato, and } \\
\text { cassava }\end{array}\end{array}$ & Rice \\
\hline & Bojonegoro & $\begin{array}{l}\text { Green bean, } \\
\text { soy, and rice }\end{array}$ & - \\
\hline & Tuban & $\begin{array}{lr}\text { Corn, } & \text { green } \\
\text { bean, } & \text { and } \\
\text { peanut }\end{array}$ & Corn \\
\hline & Bangkalan & $\begin{array}{l}\text { Green bean, } \\
\text { peanut, soy, } \\
\text { and sweet } \\
\text { potato }\end{array}$ & - \\
\hline & Sampang & $\begin{array}{l}\text { Green bean, } \\
\text { peanut, soy, } \\
\text { sweet potato, } \\
\text { and cassava }\end{array}$ & - \\
\hline & Pamekasan & Corn & - \\
\hline & Sumenep & $\begin{array}{l}\text { Corn, green } \\
\text { bean, soy, } \\
\text { and cassava }\end{array}$ & Soy \\
\hline
\end{tabular}

Source: This Study (2019)

Based on superior crops and competitive advantages in the competitiveness mentioned in each of the regions above, it can be taken into consideration by the government in making regional policies in order to accelerate economic growth in the area of East Java. Policy implications that can be carried out by the government include:

- Increasing the productivity of crops through commercial farming supported by the local market that can guarantee a fair and stable price of yields
- Efforts to increase production are prioritized in areas of production centers supported by the high demand for the food industry.

- Guaranteed the availability of adequate land, irrigation, and other inputs in each region of crops development, and the existence of agricultural extension in each region of the production center according to its potential.

- Improve the marketing system through a partnership pattern between supplier farmers and industry

- Enhancing the status of other crops than rice and corn, such as cassava and sweet potato as foodstuffs, in order to strengthen the bargaining position of producer farmers, and increase the household income of producer farmers.

- Easy procedures for accessing working capital for farmers and the private sector doing business in the field of agribusiness, especially the crops.

- Accelerating technology dissemination of research results and accelerating the application of technology at the farm level through revitalization of agricultural extension workers

- Easy to provide fertilizer for farmers, by simplifying the consumer distribution system

- Encourage the development of small businesses / households in the downstream subsystem to produce high-quality processed products in accordance with consumer demands

- Improvement and development of agricultural infrastructure in general

- $\quad$ The adequate resource allocation (HR, budget) policy in research and development (R\&D) activities in order to produce appropriate technology, especially new high yielding varieties.

\section{CONCLUSION}

According to this study finding then it can conclude as follows:

- The result of the location quotient evidence that superior crops in each region of East Java are diverse, with the most commodities being soybeans and rice, while the least commodities are peanuts and sweet potatoes. Among the 38 regions in East Java, the highest number of superior crops are Magetan, Ngawi and Sampang. Whereas the regions that have the least amount of superior crops are Situbondo, Probolinggo, Pamekasan, Probolinggo City, Pasuruan City, Madiun City, and Surabaya City.

- The results of the shift share analysis indicate that crops in 38 regions in East Java have varied values that include positive and negative values. This value is influenced by three factors in the form of regional economic growth, proportional shift and differential shift. However, more attention should be given to proportional shift values, where all values are negative. This indicates that the level of economic growth throughout the region when viewed from the 
agricultural sector tends to be slower than the economic growth of East Java Province. This phenomenon shows that the need for improvement of the agricultural sector in order to increase and accelerate regional economic growth in East Java.

- The results of the shift share analysis also show the patterns of crops growth in each region. The growth patterns of crops in the southern subregional show that cassava, corn and rice have increased production growth rates. Growth pattern in the far-southeast sub-regional, Surabaya sub-regional, and Northwest subregional show that rice and corn that have increased production growth. The sub-regional madura consists of corn, cassava and peanuts with an increased production growth rate.

\section{REFERENCES}

Akpadock, F. (1996). Diversification Trends of the Regional Economy of Mill-Town Communities in Northeast Ohio, 1980-1991. Journal of the Community Development Society, 27(2), 177-196. doi:10.1080/15575339609489806

Asfaranjan, Y., and Moayyed, A. (2012).Assessing Export Opportunity of Malaysia's Palm Oil Product: Using Shift Share Technique. European Journal of Scientific Research, 70 (2), 323-333.

BPS. (2017). Gross Regional Domestic Product of East Java Province by Industri 2013-2017. In B. P. Statistik (Ed.). Surabaya: BPS-Statistic of East Java Province

Dunn, E. S. (1960). A Statistical and Analytical Technique for Regional Analysis Papers and Procedings of the Regional Science Association, 6, 97-112.

Fernandez, Matias M. et.al. (2007). Forecasting Regional Employment with Shift Share and ARIMA Modelling. Regional Studies, Taylor Francis (Routledge), 543-551.

Fothergill, S. \& G. Gudgin. (1979). In Defence of Shift-Share. Urban Studies , 16 (3), 309- 319.

Grossi, L., anda Mussini, M. (2018). A Spatial Shift Share Decomposition of Electricity Consumption Changes Accross Italian Regions. Energy Policy 113. 278-293.

Hardiani and Lubis, Tona Aurora. (2017). Analysis of Leading Sector of Jambi City. Jurnal Perspektif Pembiayaan dan Pembangunan Daerah 5 (1).

Hassan, M. K., Rashid, Z. A., \& Hamid, K. A. (2011). East Coast Economic Region From the Perspective of Shift-Share Analysis. International Journal of Business and Society , 12 (1), 79-88.

Isserman, A. M. (1977). The Location Quotient Approach to Estimating Regional Economic
Impacts. Journal of the American Institute of Planners, $43 \quad$ (1), 33-41. doi:10.1080/01944367708977758

Kerna, Ashley and Harris, Thomas. (2009). An inputOutput Analysis of economic Diversity in Gouglas County. University of Nevada Economic Development Center.

Khusaini, Moh. (2015). A Shift-Share Analysis on Regional Competitiveness- A Case of Banyuwangi District, East Java, Indonesia. Procedia: Sosial and Behavioral Sciences 211.

Ministry of Agriculture. (2018). Outlook KomoditasPertanian Tanaman Pangan Kedelai. In K. Pertanian (Ed.). Jakarta: Pusat Data dan Sistem Informasi Pertanian.

Rahman, M., Aflah, N., Chowdhury, N., and Khan, A. (2014). Shift share Analysis of Malaysia's Export on Natural Rubber. International Journal of Business and Applied Science. Research Institute for Progression of Knowladge. Malaysia.

Reynolds, C. W. (1980). A Shift-Share Analysis of Regional and Sectoral Productivity Growth in Contemporary Mexico. Research Reports, International Institute for Applied Systems Analysis, Laxenburg, Austria.

Shi, Chun Y., and Yang, Y. (2008). A Review of Shift-Share Analysis and Its Application in Tourism. International Journal of Management Perspective. Publication of International Business and Tourism Society, 1 (1), 21-30.

Tervo, H., \& Okko, P. (1983). A Note on Shift-Share Analysis as a Method of Estimating the Employment Effects of Regional Economic Policy. Journal of Regional Science, 23 (1), $115-121$.

Widyantoro, T. (2005). Economic Growth Analysis in Lampung Province Through Basic Sector and Structural Approach 1983- 2003. (Master), University of Padjajaran, Bandung

Wilson, P., Chern, T., Ping, T., and Robinso, E. (2005). A Dynamic Shift Share Analysis of the Electronics Export Market 1988-2001: Can the NIEs Compete With China?. Singapore Centre for Applied and Policy Economics (SCAPE). Singapore.

World Bank. (2011). East Java Growth Diagnostic: Identifying the Constraints to Inclusive Growth in Indonesia's Second-Largest Provinve. Jakarta.

Wulandari, N. I. (2010). Penentuan Agribisnis Unggulan Komoditi Pertanian Berdasarkan Nilai Produksi di Kabupaten Grobogan. (Magister), Universitas Diponegoro, Semarang. 
This page is intentionally left blank 